\title{
From COVID-19 Pandemic into a Brave New World*
}

\author{
Geon Ho Bahn \\ Department of Psychiatry, Kyung Hee University School of Medicine, Seoul, Korea
}

On January 29, 2020, 'Early transmission dynamics in Wuhan, China, of novel coronavirus-infected pneumonia' was published in The New England Journal of Medicine [1]. The first 425 confirmed cases in Wuhan were documented there. Chinese scholars also published an online article about a novel coronavirus in The Lancet on January 24, 2020 [2]. I was impressed with the rapid decision of those journals that accepted these articles even without the approval of the Institutional Review Board. Contrary to hopes that further spread of the 2019 novel coronavirus disease (COVID-19) will be subsided by these quick responses, it has become a pandemic not only in China, but also around the world.

In the guest editorial, professor Young Sook Kwak introduced the Korean Society for Child Rights Advocacy, the Korean Custody Evaluation study group and special articles for Child Custody. Professor Kwak was a founding member and the first president of the Korean Society for Child Rights Advocacy. She also leads this study group, whose members are the authors of special articles in this issue. The special articles included their experiences in child and adolescent custody in recent years: 'The concept and historical background of custody evaluation' by Myung Hoon Lee; 'Custody evaluation process and report writing' by Dong Sun Chung; 'Custody Evaluation in High-conflict Situations Focused on Domestic Violence and Parental Alienation Syndrome' by Duk Soo Moon.

Due to the explosive increase in number of confirmed cases with COVID-19 in Korea since late February 2020 [3], the Ministry of Education declared that the official new school year will be pushed back in the middle of March for elementary, middle, and high schools nationwide. All kindergartens and colleges are also closed till the middle of March. During the COVID-19 outbreak, Geon Ho Bahn submitted a brief review, 'Coronavirus disease 2019, school closures and Children's Mental Health.' How should child mental health professionals deal with the mental health issues of children, especially in the wake of the new school year being postponed? Since the current outbreak was an unprecedented situation,

This is an Open Access article distributed under the terms of the Creative Commons Attribution Non-Commercial License (https://creativecommons.org/licenses/by-nc/4.0) which permits unrestricted non-commercial use, distribution, and reproduction in any medium, provided the original work is properly cited. the contents of this brief review were considered as a humble practical guideline back then. During the review of the draft submitted, the Ministry of Education announced again that school closures will be maintained until April 5, 2020. Considering the possibility of a third wave of COVID-19 in Korea [4], it is time for follow-up research papers to come out.

Interestingly, the April issue presents two brief reports focused on early adulthood. The upper limit of adolescence varies according to the law. However, people up to the age of 24 are considered adolescents in the Korea Ministry of Government Legislation [5]. Therefore, early adulthood overlaps late adolescence in the classification of adulthood. Ram Hwangbo analyzed data from National Health Insurance Service to report the diagnostic distribution of psychiatric disorders in the population aged between 19 and 30 years. Chan-Mo Yang dealt with the link between attention-deficit/hyperactivity disorder-like symptoms and a suicide attempt in young adult males (early 20s) with depression.

Last February, to my disappointment, professor Kwak, an enthusiastic member of the editorial committee, retired from Jeju University College of Medicine. All members of the editorial committee appreciate her dedication. Although she has retired according to the age set by the law, we know that she will work with passion even after retirement.

COVID-19 outbreak has thrown us a world that no one has ever experienced. Children's mental health providers will have to confront COVID-19 outbreak to protect the youth and then, "How beauteous mankind is! O brave new world, that has such people in't!."*

\section{REFERENCES}

1) Li Q, Guan X, Wu P, Wang X, Zhou L, Tong Y, et al. Early transmission dynamics in Wuhan, China, of novel coronavirus-infected pneumonia. N Engl J Med 2020 Jan 29 [Epub]. Available from URL: https://doi.org/10.1056/NEJMoa2001316.

2) Wang C, Horby PW, Hayden FG, Gao GF. A novel coronavirus outbreak of global health concern. Lancet 2020;395:470-473.

3) Korean Society of Infectious Diseases, Korean Society of Pediatric Infectious Diseases, Korean Society of Epidemiology, Korean Society for Antimicrobial Therapy, Korean Society for Healthcareassociated Infection Control and Prevention, Korea Centers for Disease Control and Prevention. Report on the epidemiological

*Shakespeare W [edited by Mowat AB, Werstine P]. The tempest, act 5, scene 1, lines 183-184. New York, NY: Simon \& Schuster;2016. 
features of coronavirus disease 2019 (COVID-19) outbreak in the Republic of Korea from January 19 to March 2, 2020. J Korean Med Sci 2020;35:e112.

4) Yoo JH. Will the third wave of coronavirus disease 2019 really come in Korea? J Korean Med Sci 2020;35:e110.
5) Korea Ministry of Government Legislation. Juvenile Activity Promotion Act, Article 2, 2014 [updated 2018 Apr 17; cited 2020 Mar 11]. Available from URL: https://elaw.klri.re.kr/kor_mobile/viewer.do?hseq=49201\&type $=$ sogan\&key $=11$. 